satellite is required, and this can only be obtained by experiment, for which the most promising area is the North Atlantic. Mr. Rippon hoped that such tests will take place in the next year or so, and said that Britain envisages putting two or three satellites into polar orbit. He also said that Britain is aiming at about 1,000 channels for an active satellite, but there is really no limit to the number of channels for a passive satellite.

Meanwhile, Britain will continue, with construction of the submarine cables to provide for the communication needs of the Commonwealth, for which a programme, costing between $£ 35$ and $£ 40$ million, has been approved, covering the cable between Canada and the United States in 1961 and Canada and Australia in 1966. The United Kingdom's share will be less, and it may be found that cable and satellite communications are complementary indefinitely. As regards a launcher, the Government has kept in being those aspects of the Blue Streak project which can be of use in developing a satellite launcher. The scientific and technological skills have been preserved, and the teams necessary to develop a satellite launcher retained : should such a launcher be developed, what Britain has done and is doing would enable her, or any other participating country, to formulate a programme and put satellites into orbit within the next five or six years. We have already concluded that, if a heavy satellite launcher were to be developed outside the United States or the U.S.S.R., there are substantial advantages for all concerned in doing so in co-operation with the Commonwealth and Europe. Mr. Rippon directed attention to the fact that Britain is keeping in close touch with Australia and Canada and other members of the Commonwealth, and, if the Blue Streak proposals are carried to completion, the facilities at Woomera will be used. The Government has also had lengthy discussions with the French Government on the joint development of a satellite launcher based on Blue Streak, and these have gone well. It is intended to ask interested countries to join in a conference early in 1961 , and in the meantime individual countries are being invited to send their experts here for discussions and to judge for themselves the technical soundness of the British proposals.

\title{
FUTURE OF THE COLONIAL AND THE COMMONWEALTH RELATIONS OFFICES
}

$I^{N}$ answer to questions in the House of Commons on December 13, the Prime Minister said that he is considering, in consultation with the Commonwealth and Colonial Secretaries, the recommendations regarding the future of the Colonial Office and the Commonwealth Relations Office made by the Select Com mittee on Estimates, and that the subject will be discussed with other Prime Ministers of the Commonwealth at their Conference to be held during March. Meanwhile, the problem of fusion is being studied to see whether some of the advantages of co-ordination can be secured without the disadvantages of combining relations with independent and dependent members in a single Office. In replying for the Government in a subsequent debate in the House of Commons on December 19, on the Select Committee's report, the Colonial Secretary, Mr. Iain Macleod, said that it is clear that the present policy of leading the dependent territories to full independence as early as is compatible with their educational, political and economic development is bound before long to lead to a stage when there is no longer justification for a separate Office, headed by a Secretary of State, to conduct the relations with the few small remaining dependencies. A Commonwealth Service is another matter, and the preference of the independent countries for independent recruitment and for local officers rather than expatriates destroys the basis of a Commonwealth Service. Meanwhile, the burden of work falling on the two Secretaries of State is too great for a merger to be practical for at least a year or two ahead. Moreover, territories which are reaching independence during the next few years will continue to require in their services expatriate officers in professional, technical and administrative posts, and the supply of such officers concerns both the Colonial Office and the Commonwealth Relations Office.

Ultimately, Mr. Macleod thought, the solution might well lie in the bringing together of the two Offices as the Select Committee recommends, but this is not yet practical politics. Meanwhile, the
Government has initiated a study of the possibility of creating a joint Department under a Minister responsible to the Colonial Secretary, the Secretary of Commonwealth Relations and the Foreign Secretary to handle under a single direction many of the forms of technical and advisory assistance which Britain provides to overseas countries whatever their status. Mr. Macleod stressed the importance of the contribution which Britain can make in technical assistance through the experience and knowledge of its men and women. It is accordingly proposed to defer consideration of the Select Committee's proposal for a Commonwealth Advisory and Technical Service pending the result of this examination. Mr. Macleod concluded with a warm tribute to the work of the Colonial Service and to the achievements of what is described as British colonialism. Britain can no longer offer many of the members of the Overseas Service the full cover which they have earned, and it is the Government's duty to ensure that everything possible is done to minimize any consequent hardship. He claimed that Britain has the finest organization in the world for providing professional and technical assistance to underdeveloped territories, and the men and women of the Overseas Service and their predecessors have a record of service of which all should be proud.

Mr. Macleod's tribute to the Colonial Service and his concern for the future of the men and women of the Overseas Service echoed what had been freely expressed in the debate, but although there appears to be widespread support for the merger of the two Offices caution was urged from both sides of the House. There is clearly concern that very big changes will be required in the Commonwealth Relations Office itself before it is fit to desl with the new situation and the needs of the newly independent members of the Commonweslth. In fact, there is much greater confidence in the ability of the Colonial Office to provide the advice, the experience, the skill and techniques that will still be required. 